15

\title{
Исследование оптических свойств многомодового кварцевого оптического волокна с отражающей оболочкой из фторированного термопластичного полимера
}

\author{
(C) А.А. Маковецкий, А.А. Замятин, Д.В. Ряховский \\ Фрязинский филиал Института радиотехники и электроники им. Котельникова РАН, \\ 141190 Фрязино, Московская обл., Россия \\ e-mail: maz226@ms.ire.rssi.ru
}

Поступила в редакцию 12.04.2018 г.

В окончательной редакции 14.04.2019 г.

Принята к публикации 07.05.2019 г.

\begin{abstract}
Экспериментально исследованы оптические свойства кварц-полимерного оптического волокна со световедущей сердцевиной диаметром $430 \mu \mathrm{m}$ и отражающей оболочкой толщиной $70 \mu \mathrm{m}$ из термопластичного сополимера тетрафторэтилена с этиленом марки Tefzel. Полимерное покрытие нанесено на кварцевое волокно фильерным способом из расплава термопласта непосредственно на вытяжной установке. Измерены оптические потери вытянутого волокна, числовая апертура и ее зависимость от длины волокна. Установлено, что при распространении света по волокну наблюдается заметное его рассеяние отражающей оболочкой, что связано с кристалличностью полимера. Измерены распределение интенсивности рассеянного излучения вдоль оси волокна и индикатриса рассеяния излучения оболочкой. Оценены относительные вклады рассеяния и поглощения света в оболочке в общие оптические потери волокна. Рассмотрена возможность использования оптических волокон данной структуры в лазерной медицине.
\end{abstract}

Ключевые слова: кварц-полимерное оптическое волокно, индикатриса рассеяния, лазерная медицина.

DOI: $10.21883 /$ OS.2019.09.48206.107-19

\section{Введение}

Многомодовые оптические волокна (ОВ) со световедущей сердцевиной из чистого кварцевого стекла диаметром 200-600 $\mu \mathrm{m}$ широко используются в лазерной медицине [1]. В настоящее время существуют два основных типа таких волокон - кварц-кварцевые ОВ и кварц-полимерные ОВ. Эти волокна различаются материалом светоотражающей оболочки. В кварц-кварцевых ОВ отражающая оболочка состоит из кварцевого стекла, легированного фтором. В кварц-полимерном ОВ отражающая оболочка состоит из кремний-органического полимера. Поверх отражающей оболочки на оба типа волокон наносят защитное покрытие, как правило, из термопластичного полимера.

Достоинством кварц-кварцевых ОВ являются их малые оптические потери, их торцы удобно механически обрабатывать, но они дороги в изготовлении и имеют сравнительно небольшую для медицинских применений числовую апертуру $(N A=0.20-0.22)$. Кварцполимерные ОВ имеют большую числовую апертуpy $(N A=0.35-0.45)$ и более низкую стоимость изготовления. Однако наличие у них двойной полимерной оболочки суммарной толщиной 80-120 $\mu \mathrm{m}$ увеличивает внешний диаметр и тем самым уменьшает максимально допустимый диаметр световедущей сердцевины при использование данных ОВ в эндоскопах и зондах с фиксированным диаметром сигнального канала.
Нами был разработан фильерный способ нанесения покрытий из расплавов термопластичных полимеров, позволяющий наносить покрытия на вытягиваемое „голое “ (без буферного слоя) кварцевое волокно непосредственно во время вытяжки [2]. Если в качестве материала для отражающей оболочки использовать фторированные термопластичные полимеры (т.е. полимеры с высоким содержанием фтора) [3], обладающие высокой механической прочностью и имеющие показатель преломления меньший, чем у кварцевого стекла, то указанным способом можно изготовить многомодовые кварцполимерные $\mathrm{OB}$, в которых отражающая оболочка одновременно является и защитной. Цель настоящей работы заключалась в исследовании оптических свойств одного из представителей таких ОВ - кварц-полимерного ОВ с отражающей оболочкой из сополимера тетрафторэтилена с этиленом марки Tefzel.

\section{Измерение оптических характеристик кварц-полимерного оптического волокна с покрытием Tefzel}

Для проведения исследований оптических параметров на вытяжной установке из кварцевого штабика КУВИ (с содержанием гидроксильных групп $10 \mathrm{ppm}$ ) были изготовлены образцы ОВ с сердцевиной диаметром $430 \mu \mathrm{m}$ и с покрытием Tefzel толщиной $70 \mu \mathrm{m}$, нанесенным на вытягиваемое волокно фильерным способом. 


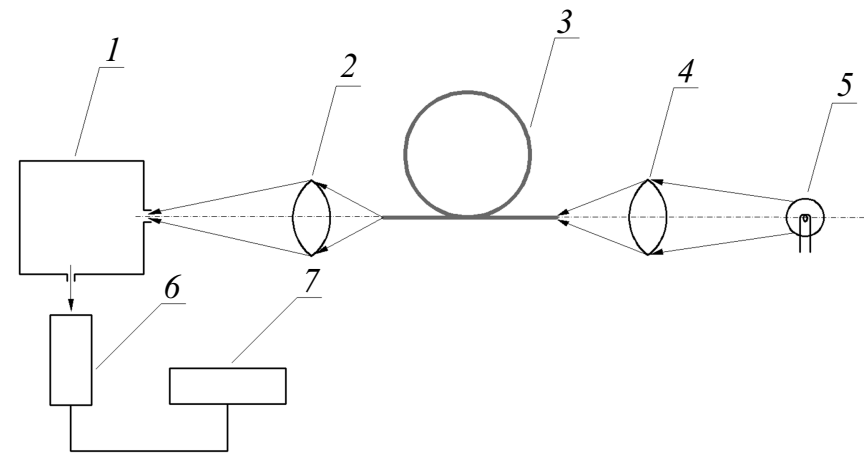

Рис. 1. Схема экспериментальной установки для измерения оптических потерь в ОВ: 1 - лампа накаливания КГМ-9-70, 2 - линза, 3 - исследуемое ОВ, 4 - конденсор монохроматора, 5 - монохроматор МДР-3, 6 - фотоприемник на основе ФЭУ-51, 7 - цифровой вольтметр В7-22А.

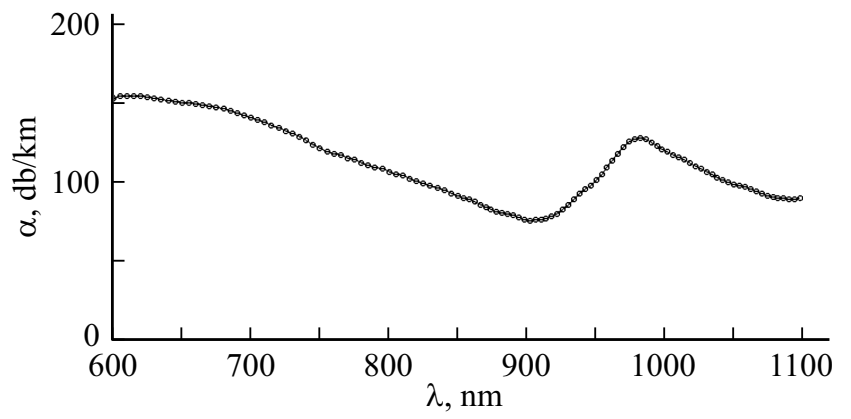

Рис. 2. Измеренная спектральная зависимость оптических потерь в кварц-полимерном ОВ с покрытием Tefzel.

Температура высокотемпературной печи с графитовым нагревательным элементом составляла $1960^{\circ} \mathrm{C}$, температура расплава термопласта $270^{\circ} \mathrm{C}$, внутренний выходной диаметр фильеры $0.8 \mathrm{~mm}$, скорость вытягивания (скорость нанесения покрытия) $1.5 \mathrm{~m} / \mathrm{min}$. Длины вытянутых волокон до $35 \mathrm{~m}$.

\section{Измерение оптических потерь ОВ}

Измерение оптических потерь было проведено методом облома [4], схема измерения приведена на рис. 1. В качестве источника засветки ОВ использовалась металлогалогеновая лампа накаливания КГМ-9-70. Величину потерь $\alpha_{\lambda}$ на длине волны $\lambda$ рассчитывали по формуле

$$
\alpha_{\lambda}=10 \lg \left(\frac{I_{\lambda}\left(l_{1}\right)}{I_{\lambda}\left(l_{2}\right)}\right)\left(l_{2}-l_{1}\right)^{-1},
$$

где $l_{1}$ и $l_{2}$ - длины измеряемых отрезков $\mathrm{OB}, I_{\lambda}\left(l_{1}\right)$ и $I_{\lambda}\left(l_{2}\right)$ - интенсивности сигналов на их выходе.

Результаты измерений оптических потерь в исследованном ОВ в спектральном диапазоне $600-1100 \mathrm{~nm}$ приведены на рис. 2. Измерения были проведены в отрезках $\mathrm{OB}$ длиной $l_{1}=30 \mathrm{~m}$ и $l_{2}=2 \mathrm{~m}$. Результаты измерений составили $75-150 \mathrm{db} / \mathrm{km}$, погрешность измерений $3 \mathrm{db} / \mathrm{km}$. Это существенно больше оптических потерь в сердцевине данного ОВ, оцениваемых в $10-15 \mathrm{db} / \mathrm{km}$ по концентрации гидроксильных групп [5]. Тем не менее, светопропускание в коротких (длиной 2-5m) образцах таких ОВ составляет $0.85-0.95$, что достаточно для применений в медицинских целях.

Заметим, что при распространении света по кварцполимерному ОВ с отражающей оболочкой Tefzel визуально наблюдалось сильное рассеяние оболочкой, особенно на начальном участке. Оно было видно под любым углом наблюдения к оси ОВ. В последующих экспериментах были оценены вклады поглощения и рассеяния света в отражающей оболочке в оптические потери ОВ.

\section{Измерение числовой апертуры ОВ}

Эффективная числовая апертура $N A_{\text {ef }}$ вытянутых ОВ была оценена по измерениям углового распределения интенсивности излучения $J(\varphi)$ в дальней зоне по стандартной методике [6]. Схема измерения приведена на рис. 3. В качестве источника засветки использовался Не-Ne-лазер. Фотоприемник ФЭУ-51 через диафрагму диаметром $5 \mathrm{~mm}$ регистрировал выходной сигнал ОВ. Расстояние от выходного торца ОВ до светочувствительного слоя фотоприемника составляло $220 \mathrm{~mm}$. Угол наблюдения $\varphi$ (угол между осью волокна и нормалью к светочувствительному слою фотоприемника) изменялся в эксперименте в пределах $\pm 45^{\circ}$. За величину эффективного апертурного угла $\varphi_{\text {ef }}$ был принят угол, при котором интенсивность поля излучения уменьшается до $5 \%$ от максимальной интенсивности. При этом эффективная числовая апертура рассчитывалась по формуле $N A_{\text {ef }}=\sin \left(\varphi_{\text {ef }}\right)$.

Примеры измеренных угловых распределений интенсивности поля излучения в дальней зоне для ОВ различной длины и построенная по ним зависимость эффективной числовой апертуры от длины волокна приведены на рис. 4. Заметим, что показатели преломления Tefzel и кварцевого стекла равны соответственно $n_{t}=1.394$ [3] и $n_{s}=1.457$ [7]. Это соответствует номинальной числовой апертуре ОВ $N A=\sqrt{n_{s}^{2}-n_{t}^{2}}=0.425$. Из приведенной

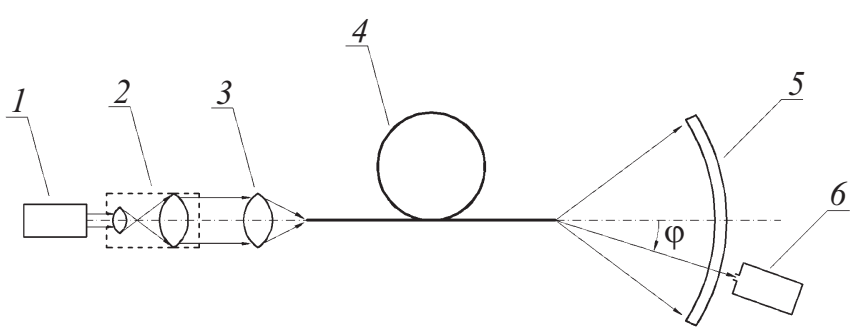

Рис. 3. Схема экспериментальной установки для измерения углового распределения интенсивности поля излучения ОВ в дальней зоне: 1 - Не-Ne-лазер, 2 - расширитель лазерного луча, 3 - фокусирующая линза, 4 - исследуемое ОВ, 5 гониометр, 6 - фотоприемник ФЭУ-51. 

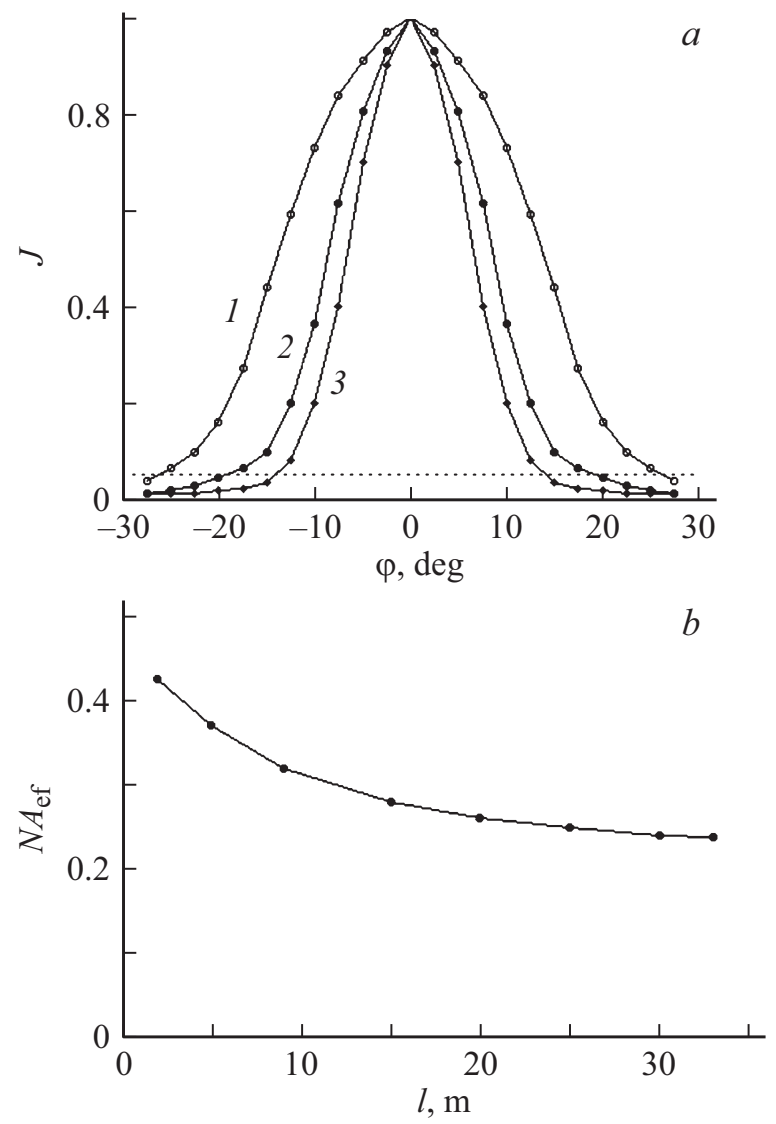

Рис. 4. $a-$ измеренные угловые распределения относительной интенсивности излучения кварц-полимерного ОВ с покрытием Tefzel в дальней зоне для волокон длиной 2 (1), $9(2), 30 \mathrm{~m}(3) ; b-$ измеренная зависимость эффективной числовой апертуры ОВ от длины волокна.

на рис. $4, b$ кривой видно, что при увеличении длины ОВ от 2 до $33 \mathrm{~m}$ эффективная числовая апертура OB уменьшается от исходного значения 0.425 (равного номинальной числовой апертуре) до 0.25 . Это связано с тем, что моды высших порядков глубже заходят в отражающую оболочку и затухают сильнее, чем моды более низких порядков [8].

\section{Измерение интенсивности излучения, рассеянного отражающей оболочкой Tefzel}

Сначала было измерено распределение интенсивности рассеянного излучения по длине ОВ. Рассеяние света в полимере Tefzel связано с его кристалличностью, т.е. наличием в материале кристаллической и аморфной фаз, имеющих различные значения показателя преломления. Схема регистрации рассеянного излучения приведена на рис. 5, a. Измеренные зависимости нормированной интенсивности рассеянного излучения от расстояния до входного торца ОВ при засветках излучениями лампы накаливания и Не-Nе-лазером представлены на рис. 5, $b$. При засветке ОВ лампой накаливания построенная кри- вая спадает круче, чем соответствующая кривая для лазера. Это связано с величиной входной апертуры возбуждающего излучения, у лампы накаливания она выше, чем у лазера - 0.4 и 0.05 соответственно.

Отметим, что интенсивность рассеянного оболочкой излучения на расстоянии $l$ от входного торца ОВ $J_{s}(l)$ пропорциональна интенсивности распространяющегося по ОВ излучения $\mathrm{I}(1): J_{s}(l) \sim I(l)$. Следовательно, по кривой $J_{s}(l)$ можно оценить оптические потери по формуле, аналогичной формуле (1) метода „облома“:

$$
\alpha=10 \lg \left(\frac{J_{s}\left(l_{1}\right)}{J_{s}\left(l_{2}\right)}\right)\left(l_{2}-l_{1}\right)^{-1} .
$$

Место первого измерения рассеяния следует выбирать ближе к входному торцу ОВ $\left(l_{1}=1.0 \mathrm{~m}\right)$, второго к выходному. По кривой 2 рис. $5, b$, соответствующей рассеянию монохроматического излучения с длиной волны $\lambda=0.63 \mu \mathrm{m}$, полагая $l_{2}=18 \mathrm{~m}$, получим $\alpha_{0.63} \approx 188 \mathrm{db} / \mathrm{km}$. Это больше значения оптических потерь, полученных методом „облома“ $(155 \mathrm{db} / \mathrm{km})$. Для более корректной оценки оптических потерь величина $l$ должна составлять несколько десятков метров.

Затем была измерена индикатриса рассеяния отражающей оболочки. Схема измерения приведена на рис. $6, a$. Исследуемое ОВ длиной $9 \mathrm{~m}$ было возбуждено из-
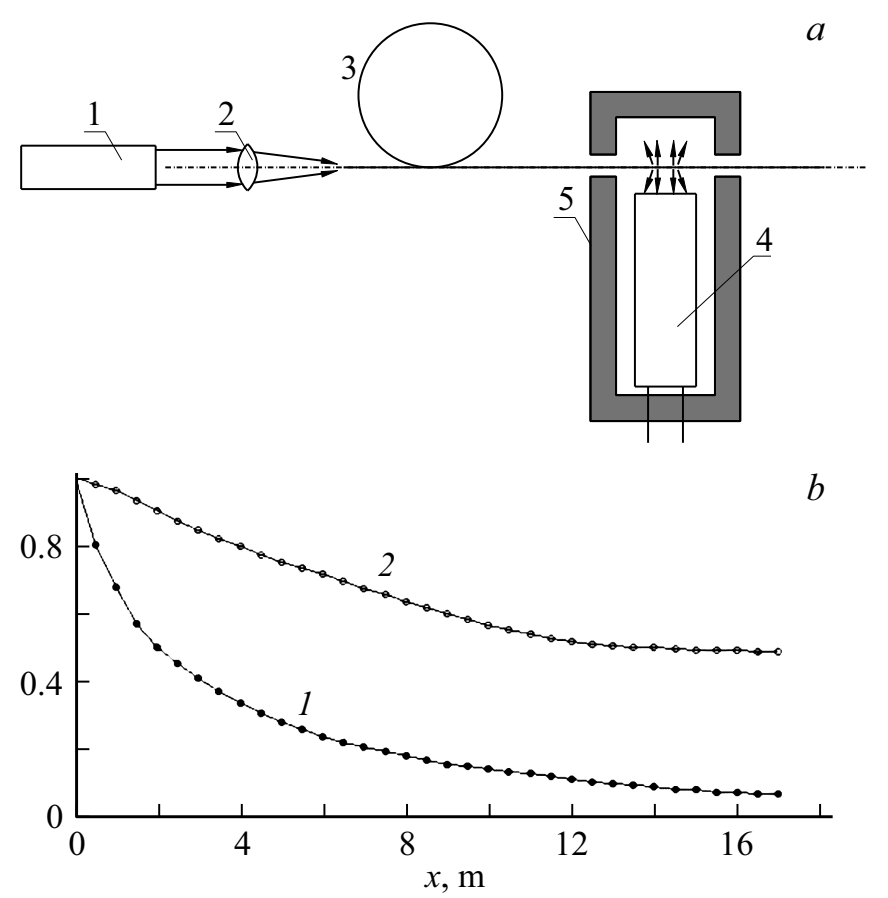

Рис. 5. $a-$ схема измерения рассеянного отражающей оболочкой излучения в кварц-полимерном ОВ с покрытием Tefzel $(1-$ источник возбуждения, 2 - фокусирующая линза, 3 - исследуемое ОВ, 4 - фотоприемник ФЭУ-51, 5 - кожух фотоприемника). $b$ - измеренные зависимости нормированной интенсивности рассеянного излучения $J(l)=J_{s}(l) / J_{s}(1.0)$ от длины $x$ участка ОВ от входного торца до места регистрации сигнала фотоприемником при возбуждении ОВ лампой накаливания КГМ-9-70 (1), Не-Ne-лазером (2). 

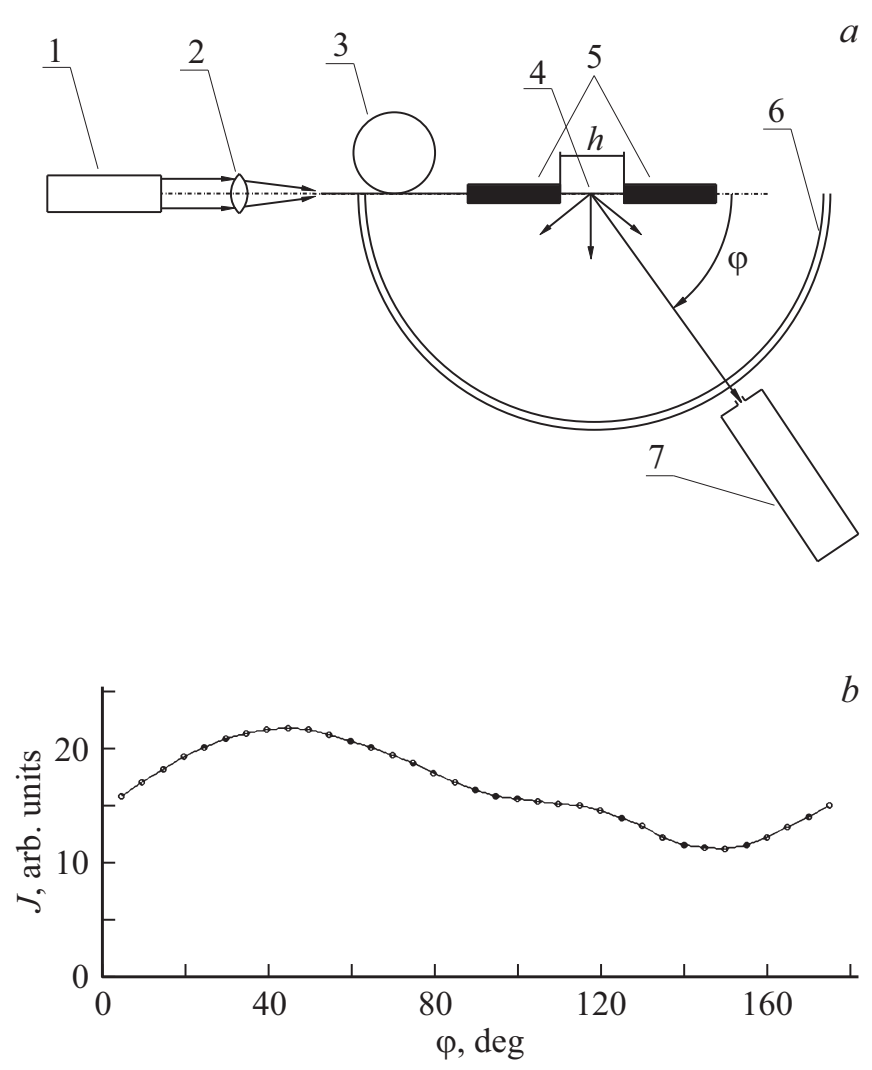

Рис. 6. $a-$ схема измерения индикатрисы рассеяния излучения отражающей оболочкой в кварц-полимерном ОВ с покрытием Tefzel: 1 - Не-Ne-лазер, 2 - фокусирующая линза, 3 исследуемое $\mathrm{OB}, 4$ - открытый участок ОВ длиной $10 \mathrm{~mm}$, 5 - экранирующие трубочки на ОВ, 6 - гониометр, 7 ФЭУ-51; $b$ - измеренная индикатриса рассеяния.

лучением Не-Ne-лазера мощностью $1.5 \mathrm{~mW}$. Числовая апертура выходящего из ОВ излучения составляла 0.32 . В эксперименте регистрировалось излучение, рассеянное участком оболочки длиной $h=10 \mathrm{~mm}$, находившимся на расстоянии $5 \mathrm{~cm}$ от конца ОВ. Расстояние от источника рассеяния до фотоприемника составляло $220 \mathrm{~mm}$, интервал углов наблюдения $\varphi=5-175^{\circ}$, шаг измерений $5^{\circ}$, угловое разрешение системы регистрации $\approx 1^{\circ}$. Отметим, что близкая по постановке задача была рассмотрена в работе [9], но в ней измерялось боковое рассеяние в кварцевом ОВ на границе германосиликатной сердцевины и силикатной отражающей оболочки.

Измеренная индикатриса рассеяния приведена на рис. $6, b$. Из приведенной кривой следует, что излучение рассеивается практически в пределах полного телесного угла, что совпадает с визуальным наблюдением рассеянного излучения.

По нашему мнению, наблюдаемое в эксперименте излучение - это рассеяние эванесцентных частей мод, распространяющихся по отражающей полимерной оболочке ОВ. Рассеяние происходит в слое оболочки толщиной порядка длины волны излучения у границы раздела сердцевина-оболочка. Длина пути первично рассеянного излучения от границы раздела сердцевина- оболочка до выхода из оболочки составляет $s=70-700 \mu \mathrm{m}$ (в зависимости от угла наблюдения). Суммарный показатель ослабления $\alpha_{\Sigma}=\alpha_{a}+\alpha_{s}$ на $\lambda=0.63 \mu \mathrm{m} \mathrm{состав-}$ ляет $1.31 \mathrm{~mm}^{-1}$. Здесь $\alpha_{a}-$ показатель поглощения, $\alpha_{s}$ - показатель рассеяния (оценки этих величин сделаны ниже). Это соответствует коэффициенту ослабления первично рассеянного излучения $\exp \left(-\alpha_{\Sigma} s\right)=0.91-0.4$. Поэтому рассеянное излучение надежно регистрируется фотоприемником.

Зависимость интенсивности эванесцентной части волны от расстояния $x$ от границы раздела сердцевина-оболочка можно задать выражением $I_{e}(x)=I_{e 0} \exp \left(-\alpha_{e} x\right)$, где $\alpha_{e}$ - величина порядка $\lambda^{-1}$, т. е. $\alpha_{e} \approx 1.59 \cdot 10^{3} \mathrm{~mm}^{-1}$. Из сравнения $\alpha_{\Sigma}$ и $\alpha_{e}$ следует, что ослабление наблюдаемого первично рассеянного излучения на три порядка меньше, чем радиальное ослабление эванесцентной части волны.

Заметим также, что оптические потери в материале полимерной оболочки исследуемого ОВ существенно выше (на порядки) оптических потерь в кварцевом стекле сердцевины. Поэтому поддержание эванесцентной части волны при ее распространении по ОВ происходит за счет непрерывного тунелирования излучения из световедущей сердцевины в отражающую оболочку.

\section{Измерение светопропускания и рассеяния излучения пленкой Tefzel}

Для косвенной оценки влияния оптических свойств материала отражающей оболочки на оптические потери исследованных ОВ были проведены эксперименты по оценке поглощения и рассеяния света в пленке Tefzel толщиной $h=1 \mathrm{~mm}$. Они были выполнены по методикам измерения оптических параметров полимеров, изложенных в работе [10].

Схема измерения спектральной зависимости коэффициента светопропускания пленки Tefzel аналогична схеме измерения спектральных потерь ОВ (с заменой в ней OB на исследуемую пленку). Параметры конденсора, монохроматора и фокусирующей линзы лампы накаливания согласованы так, что при отсутствии пленки излучение лампы накаливания полностью заполняло входную апертуру конденсора. При установке пленки на вход монохроматора попадало коллинеарно прошедшее через пленку (в пределах малого телесного угла) излучение лампы накаливания. Излучение, рассеянное за пределы апертурного угла конденсора, на вход монохроматора не попадало. Следовательно, в этой схеме фотоприемником регистрировалось суммарное (за счет поглощения и рассеяния) ослабление сигнала пленкой толщиной $h$ :

$$
I(h)=I_{0} \exp \left(-\left(\alpha_{s}+\alpha_{a}\right) h\right),
$$

где $I_{0}$ - интенсивность падающего излучения.

Результаты измерений коэффициента светопропускания $\chi=I / I_{0}$ пленки Tefzel толщиной $1 \mathrm{~mm}$ приведены 


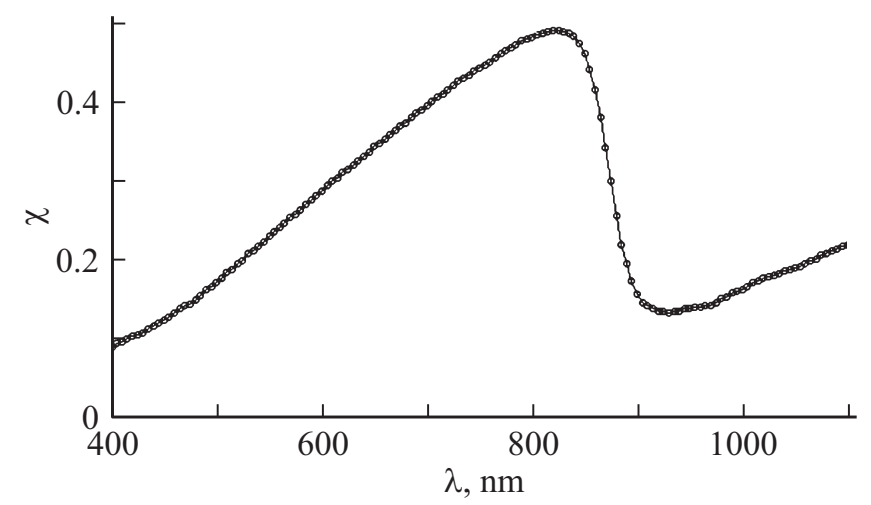

Рис. 7. Измеренная спектральная зависимость коэффициента светопропускания $\chi$ пленки Tefzel толщиной $1 \mathrm{~mm}$.

на рис. 7. В спектральном диапазоне 400-1100 nm он составил величины $0.1-0.5$, что соответствует оптическим потерям $2.6 \cdot 10^{6}-1.0 \cdot 10^{7} \mathrm{db} / \mathrm{km}$. Это на четыре порядка выше измеренных значений оптических потерь в кварц-полимерном ОВ с покрытием из этого же материала толщиной $70 \mu \mathrm{m}$. Столь высокие потери в пленке качественно можно объяснить высокой концентрацией „красящих“ примесей, а также сильным светорассеянием на оптических неоднородностях в полимере. Этим же можно объяснить и столь сложный характер спектрального светопропускания полимера.

Схема измерения индикатрисы рассеяния излучения пленкой Tefzel аналогична схеме измерения углового распределения интенсивности поля излучения ОВ в дальней зоне (рис. 3). Исследуемая пленка была установлена на месте выходного торца ОВ, при ее засветке не использовались расширитель лазерного луча $\mathrm{He}-\mathrm{Ne}$ лазера и фокусирующая линза. Это позволило регистрировать рассеянное пленкой излучение в интервале углов наблюдения $0-175^{\circ}$.

Измеренная индикатриса рассеянного излучения $J(\varphi)$ приведена на рис. 8. Измерения были проведены для дискретного числа углов с шагом $1^{\circ}$ и $5^{\circ}$. Сделаем по ней оценки показателей поглощения и рассеяния в полимере Tefzel. B силу осевой симметрии рассеянного излучения по плоской индикатрисе можно рассчитать индикатрису в пределах полного телесного угла. Пусть $I_{0}$ - интенсивность падающего на пленку излучения Не$\mathrm{Ne}$-лазера, $I_{1}$ - поток коллинеарно прошедшего через пленку излучения, $I_{2}-$ суммарный поток рассеянного излучения. Введенные величины связаны между собой соотношениями

$$
I_{1} \approx I_{0} \exp \left(-\left(\alpha_{a}+\alpha_{s}\right) h\right), I_{2} \approx I_{0}\left(1-\exp \left(-\alpha_{s} h\right)\right) .
$$

Отсюда следует выражение для коэффициента ослабления излучения за счет рассеяния $\alpha_{s}$ :

$$
\exp \left(-\alpha_{s} h\right)=1-\left(\frac{I_{2}}{I_{1}}\right) \exp \left(-\left(\alpha_{a}+\alpha_{s}\right) h\right)
$$

Заметим, что в формулу (4) входит отношение величин $I_{1}$ и $I_{2}$. Поэтому нет необходимости измерять их абсолютные значения. Достаточно определить величины, пропорциональные искомым потокам: $s_{1} \sim I_{1}, s_{2} \sim I_{2}$, где $s_{1}-$ поверхностный интеграл от индикатрисы рассеяния по сферическому сегменту, соответствующему коллинеарному лучу, $s_{2}-$ поверхностный интеграл по дополнительному (к коллинеарному) сферическому сегменту. В расчетах радиус сферы был принят $R=220 \mathrm{~mm}$ (расстояние от пленки до чувствительного слоя ФЭУ-51). Заменив интегрирование суммированием и опустив промежуточные вычисления, в результате получили $I_{1} / I_{2} \approx 2.48$. На длине волны $\lambda=0.63 \mu \mathrm{m}$ суммарное ослабление сигнала $\exp \left(-\left(\alpha_{a}+\alpha_{s}\right) h\right)=0.27$ (рис. 7). Подставив в (2) значения исходных параметров, получим $\exp \left(-\alpha_{s} h\right)=0.33$ и $\exp \left(-\alpha_{a} h\right)=0.82$. Для показателей поглощения $\alpha_{a}$ и рассеяния $a_{s}$ отсюда следуют значения: $\alpha_{a}=0.20 \mathrm{~mm}^{-1}$ и $\alpha_{s}=1.11 \mathrm{~mm}^{-1}$ $\left(\alpha_{\Sigma}=1.31 \mathrm{~mm}^{-1}\right)$. Из сравнения величин $\alpha_{a}$ и $\alpha_{s}$ следует, что главным механизмом оптических потерь в материале Tefzel являются потери на рассеяние.
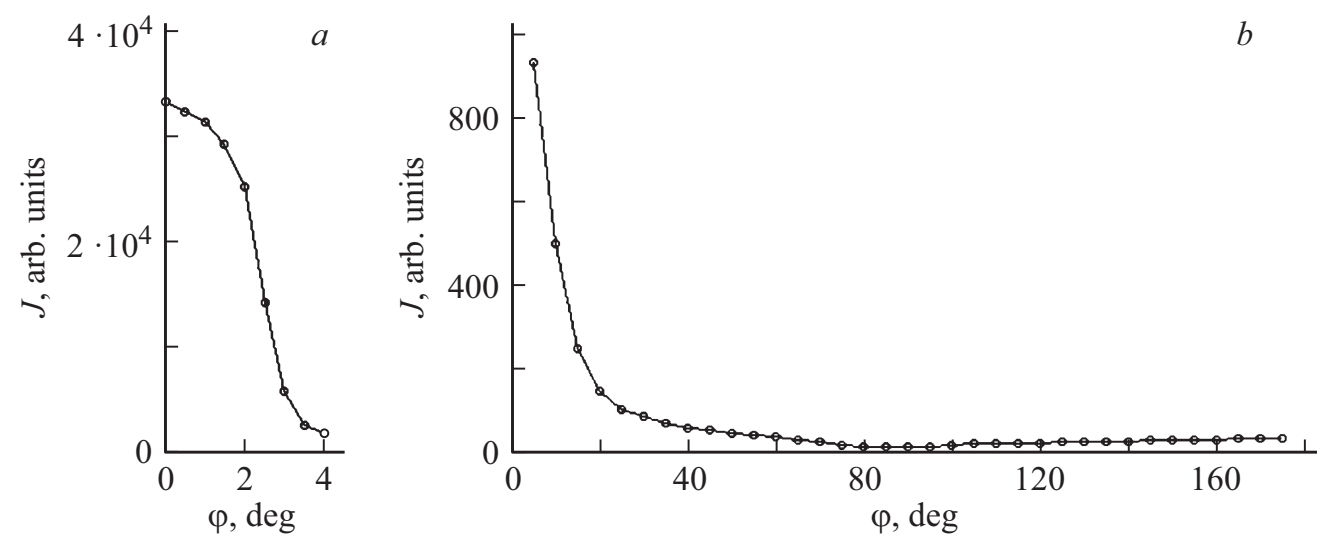

Рис. 8. Измеренная индикатриса рассеяния пленкой Tefzel излучения Не-Ne-лазера (толщина пленки $1 \mathrm{~mm}) . a-$ для углов $0-4^{\circ}$, $b$ - для углов $5-175^{\circ}$. 


\section{Заключение}

В заключение сформулируем основные результаты работы.

1. Фильерным способом изготовлено кварц-полимерное ОВ с однослойным покрытием из термопластичного сополимера тетрафторэтилена с этиленом марки Tefzel, совмещающим в себе функции отражающего и защитного покрытий.

2. Экспериментально исследованы оптические свойства сформированных ОВ. Установлено, что распространение света по данным ОВ сопровождается значительным рассеянием света отражающей оболочкой Tefzel, что связано с кристалличностью использованного полимера.

3. Несмотря на наличие дополнительных оптических потерь за счет рассеяния света отражающей оболочкой, образцы таких волокон длиной в несколько метров пригодны к использованию в лазерной медицине.

\section{Конфликт интересов}

Авторы заявляют, что у них нет конфликта интересов.

\section{Список литературы}

[1] Тучин В.В. Лазеры и волоконная оптика в биомедицинских исследованиях. М: Физматлит, 2010. 488 с.

[2] Замятин А.А., Иванов Г.А., Маковецкий А.А., Шилов И.П. Патент РФ № 2402497. 2008.

[3] French R.H., Rodríguez-Parada J.M., Yang M.K et al. // Solar Energy Materials and Solar Cells. 2011. V. 95. N 8. P. 2077.

[4] Листвин А.В., Листвин В.Н. Рефлектометрия оптических волокон. М.: ЛЕСАРарт, 2008. 208 с.

[5] Бурков В.Д., Иванов Г.А. Физико-технологические основы волоконно-оптической техники. М: Изд-во Моск. гос. ун-та леса, 2007. 222 с.

[6] Cherin A.H., Rich J. // Appl. Opt. 1978. V. 17. N 4. P. 642.

[7] Краткий физико-технический справочник. Т. 1 / Под ред. К.П. Яковлева. М: Физматлит, 1960. 446 с.

[8] Введение в интегральную оптику / Под ред. М. Барновски. М.: Мир, 1977. 368 c.

[9] Алексеев В.В., Лихачев М.Е., Бубнов М.М. и др. // Квант. электрон. 2011. Т. 41. № 10. C. 917; Alekseev V.V., Likhachev M.E., Bubnov M.M. et al. // Quant. Electron. 2011. V. 41. N 10. P. 917.

[10] Ross G., Birley A.W. // J. Phys. D. 1973. V. 6. P. 795. 